\title{
ANALISIS USAHA PEMANFAATAN KULIT DAGING BUAH KOPI FERMENTASI DENGAN MIKROORGANISME LOKAL DALAM PAKAN KERBAU MURRAH (Bubalus bubalis) JANTAN LEPAS SAPIH
}

\section{(The Economic Analysis of Utilization Fermented Coffee Peel by Local Microorganism in Feed of Murrah Male Buffalo (Bubalus bubalis))}

\author{
Emmy Kejora ${ }^{1}$, Iskandar Sembiring ${ }^{2}$ dan Nurzainah Ginting ${ }^{2}$ \\ 1 Mahasiswa Program Studi Peternakan Fakultas Pertanian Universitas Sumatera Utara \\ 2 Staf Pengajar Program Studi Peternakan Fakultas Pertanian Universitas Sumatera Utara
}

\begin{abstract}
Fermented coffee peel by local microorganism have good nutrition and relatively inexpensive, can improve the efficiency and ultimately the cost of feed to increase revenue. The experiment was conducted in the Balai Pembibitan Ternak Unggul Babi dan Kerbau at Silangit village Siborong-borong subdistrict North Tapanuli District, North Sumatera Province, from $2{ }^{\text {nd }}$ April 2012 to $31^{\text {st }}$ August 2012. The aims of research was to determine economic value of fermented coffee peel by local microorganisms in feed Murrah buffalo male (Bubalus bubalis). The treatments were P0 (20\% of coffee peel without fermentation), P1 (10\% of coffee peel fermented), P2 (20\% of coffee peel fermented), P3 (30\% of coffee peel fermented). The results showed that the highest profit was in the treatment of $\mathrm{P} 1$, i.e. Rp. 315.254,- and the lowest profit was in the treatment of $\mathrm{P} 0$, i.e. Rp.138.245,-. The highest benefit cost ratio (B/C) was in the treatment of P1, i.e. 1.05 and the lowest was in the treatment of P0, i.e. 1,02. The highest Income Over Feed Costs (IOFC) was in the treatment of P1, i.e. Rp. 394.754 ,- and the lowest was in the treatment of P0, i.e Rp. 217.745,-. The conclusion that the fermented coffee peel by local microorganisms can use as alternative feed ingredients for the Murrah buffalo feed.
\end{abstract}

Keywords: Economic analysis, coffee peel, fermentation, local microorganisms, male Murrah buffalo.

\begin{abstract}
ABSTRAK
Kulit daging buah kopi fermentasi dengan mikroorganisme lokal mempunyai kandungan nutrisi yang baik, harganya relatif murah, dapat meningkatkan efisiensi biaya pakan dan pada akhirnya mampu meningkatkan pendapatan. Penelitian dilaksanakan di Balai Pembibitan Ternak Unggul Babi dan Kerbau di Desa Silangit Kecamatan Siborong-borong Kabupaten Tapanuli Utara, Sumatera Utara yang dilaksanakan pada tanggal 2 April 2012 sampai dengan 31 Agustus 2012. Penelitian ini bertujuan untuk mengetahui nilai usaha dari pemanfaatan kulit daging buah kopi fermentasi dengan mikroorganisme lokal dalam pakan kerbau murrah jantan (Bubalus bubalis) lepas sapih. Adapun perlakuan dalam penelitian ini adalah P0 (20\% kulit daging buah kopi tanpa fermentasi), P1 (10\% kulit daging buah kopi fermentasi), P2 (20\% kulit daging buah kopi fermentasi), P3 (30\% kulit daging buah kopi fermentasi). Hasil penelitian menunjukkan bahwa rataan laba tertinggi adalah pada perlakuan P1 memberikan keuntungan sebesar Rp. 315.254.- dan terkecil pada perlakuan P0 dengan memberikan keuntungan sebesar Rp. 138.245.-. Rataan benefit cost ratio (B/C) tertinggi adalah pada perlakuan P1 sebesar 1.05 dan terkecil pada perlakuan P0 sebesar 1.02. Rataan Income Over Feed Cost (IOFC) tertinggi pada perlakuan P1 sebesar Rp. 394.754.- dan yang terendah pada perlakuan P0 sebesar Rp. 217.745.-Kesimpulan adalah pemanfaatan kulit daging buah kopi yang difermentasai dengan mikroorganisme lokal dapat digunakan sebagai bahan pakan alternatif pada pakan kerbau Murrah.
\end{abstract}

Kata kunci: Analisis usaha, kulit daging buah kopi, fermentasi, mikroorganisme lokal, kerbau Murrah jantan.

\section{PENDAHULUAN}

Usaha dan pengembangan peternakan pada saat ini menunjukkan prospek yang sangat cerah dan mempunyai peranan yang sangat penting dalam pertumbuhan ekonomi pertanian. Hal ini terbukti dari kebutuhan bahan pangan khususnya yang berasal dari hewani seperti 
daging, susu dan telur dari tahun ketahun semakin meningkat, sejalan dengan meningkatnya jumlah penduduk, tingkat pendidikan dan kesadaran masyarakat akan peranan zat-zat makanan khususnya protein hewani bagi kehidupan. Selain itu, industri produk pengolahan hasil ternak juga terus berkembang seiring dengan berkembangnya daerah perkotaan.

Ternak kerbau khususnya ternak kerbau Murrah merupakan salah satu komoditas peternakan yang mempunyai keistimewaan tersendiri dibanding dengan ternak sapi. Dimana ternak kerbau Murrah mampu hidup di kawasan marjinal terutama bila pakan yang tersedia berkualitas sangat rendah. Kerbau Murrah juga dapat digunakan sebagai sumber tenaga kerja. Selain itu, dagingnya mampu menunjang program swasembada daging tahun 2014. Susu dari ternak kerbau Murrah banyak diolah menjadi produk bahan pangan, contohnya sebagai bahan baku pembuatan keju Mozzarella dan produk lainnya yang dikenal dengan berbagai nama seperti dadih (Sumatera Utara), dadiah (Sumatera Selatan dan Sumatera Barat), danke (Sulawesi Selatan), susu goring (NTT). Kulit kerbau sering digunakan juga sebagai bahan sepatu, wayang kulit dan helm sepeda motor, sehingga kerbau mempunyai peluang usaha yang menjanjikan untuk dikembangkan.

Salah satu faktor yang berpengaruh dalam keberhasilan pengelolaan ternak adalah faktor pakan, Tillman (1991). Faktor pakan bergantung terhadap faktor iklim, karena pada masa musim hujan pakan melimpah dan waktu musim kemarau kekurangan pakan, dan untuk mengatasi hal ini perlu dilakukan pengawetan pakan terutama sisa hasil pertanian dan perkebunan yang berpotensi untuk dimanfaatkan karena jumlahnya yang melimpah dan harganya murah.

Bahan pakan alternatif yang dapat digunakan sebagai bahan pakan untuk ternak adalah kulit daging buah kopi. Kulit daging buah kopi merupakan komponen terbesar dari pengolahan kopi yang sampai sekarang kebanyakan hanya digunakan untuk bahan pupuk organik/kompos di perkebunan itu sendiri. Dilihat dari kandungan serat kasar beserta zat-zat pakan yang terdapat di dalamnya, kulit daging buah kopi mempunyai potensi untuk dijadikan bahan pakan ternak, namun pemanfaatan kulit daging buah kopi mempunyai faktor pembatas karena mengandung tannin, kafein dan lignin. Untuk menurunkan pembatas itu, diperlukan pengolahan lebih lanjut, salah satunya dengan menerapkan proses fermentasi. Dengan proses demikian diperoleh bahan pakan yang mengandung nilai gizi yang dibutuhkan oleh ternak, jumlahnya banyak tersedia, harganya murah dan nilai gizinya baik yang mampu meningkatkan pendapatan peternak.

Analisis usaha peternakan merupakan salah satu kegiatan penting dalam usaha peternakan dan merupakan pekerjaan rutin perusahan peternakan yang dilakukan untuk mengetahui kelayakan suatu usaha peternakan. Berdasarkan pemikiran di atas, penulis 
tertarik untuk melakukan analisis usaha melalui penelitian terhadap usaha penggemukan kerbau Murrah jantan lepas sapih dengan menggunakan pakan berbasis limbah perkebunan berupa kulit daging buah kopi yang difermentasi.

\title{
BAHAN DAN METODE
}

\section{Lokasi dan Waktu Penelitian}

Penelitian dilaksanakan di Balai Pembibitan Ternak Unggul Babi dan Kerbau di Desa Silangit Kecamatan Siborong-borong Kabupaten Tapanuli Utara, Sumatera Utara. Penelitian ini dilaksanakan pada bulan April sampai dengan Agustus 2012.

\section{Bahan dan Alat Penelitian}

Bahan

Bahan yang digunakan dalam penelitian adalah 4 ekor ternak Kerbau Murrah jantan lepas sapih sebagai objek yang akan diteliti, hijauan lapangan, konsentrat yang terdiri dari kulit daging buah kopi, dedak padi, bungkil inti sawit, jagung, molases, urea, garam dan ultra mineral sebagai bahan pakan. Air tebu, ragi tempe, ragi tape dan youghurt sebagai bahan fermentor pembuatan inokulan cair serta obat-obatan seperti obat cacing, vitamin B-Kompleks dan air minum.

\begin{abstract}
Alat
Alat yang digunakan dalam penelitian ini adalah kandang individual 4 unit beserta perlengkapanya, tempat pakan dan minum, timbangan digital, terpal plastik untuk menjemur bahan pakan, alat kebersihan (sapu lidi, ember, karung goni plastik, sekop), alat tulis, kalkulator dan alat penerangan.
\end{abstract}

\section{Metode Penelitian}

Rancangan penelitian yang digunakan dalam penelitian adalah rancangan bujur sangkar latin 4 perlakuan. Perlakuan yang diteliti adalah :

P0 = Hijauan Lapangan + konsentrat tanpa kulit buah kopi tanpa fermentasi

P1 = Hijauan Lapangan + konsentrat dengan kulit buah kopi fermentasi $10 \%$

P2 = Hijauan Lapangan + konsentrat dengan kulit buah kopi fermentasi 20\%

P3 = Hijauan Lapangan + konsentrat dengan kulit buah kopi fermentasi 30\%

$\mathrm{K} 1=$ Kerbau pertama

K2 $=$ Kerbau kedua

K3 = Kerbau ketiga

K4 = Kerbau keempat 
Model matematika yang digunakan menurut Sastrosupadi (2000) adalah :

$$
\mathbf{Y}_{\mathrm{ijk}}=\boldsymbol{\mu}+\mathbf{T}_{\mathbf{i}}+\mathbf{B}_{\mathbf{j}}+\mathbf{K}_{\mathbf{k}}+\boldsymbol{\epsilon}_{\mathrm{ijk}}
$$

Keterangan :

$\mathrm{Y}_{\mathrm{ijk}}=$ hasil pengamatan dari perlakuan ke-i, baris ke-j dan kolom ke-k

$\mathrm{T}_{\mathrm{i}}=$ pengaruh perlakuan ke-i

$\mathrm{B}_{\mathrm{j}}=$ pengaruh baris ke- $\mathrm{j}$

$\mathrm{K}_{\mathrm{k}}$ = pengaruh kolom ke-k

$\mu \quad=$ nilai tengah umum

$€_{\mathrm{ijk}}=$ pengaruh galat karena perlakuan ke-i, baris ke-j dan kolom ke-k

\section{Pelaksanaan Penelitian}

Pengolahan Kulit Kopi

- Pembuatan inokulan cair;

Dimasukkan air sumur, air tebu, ragi tempe, ragi tape dan youghurt kedalam galon, diaduk lalu ditutup dengan plastik dan didiamkan selama 3 hari.

- Pembuatan kulit daging buah kopi fermentasi;

Dicampur dedak dengan kulit daging buah kopi segar, lalu disiram dengan inokulan cair sampai merata, kemudian ditutup, selama lima hari dibolak-balik dan diukur suhunya, lalu dibongkar dan diangin-anginkan \pm 7 hari (tidak menggumpal lagi).

\section{Parameter Penelitian}

Analisis Usaha

Total Biaya Produksi

Total biaya produksi atau total pengeluaran yaitu biaya-biaya yang dikeluarkan untuk menghasilkan suatu produk, diperoleh dengan cara menghitung: biaya bibit, biaya kandang dan peralatan, biaya pakan, biaya obat - obatan dan biaya tenaga kerja.

\section{Total Hasil Produksi}

Total hasil produksi atau total penerimaaan yaitu seluruh pendapatan dari penjualan produk yang dihasilkan dalam kegiatan ekonomi diperoleh dengan cara menghitung : harga jual kerbau dan harga jual kotoran kerbau.

\section{Analisis Ekonomi (Laba/Rugi)}

Keuntungan (laba) suatu usaha dapat diperoleh dengan cara menghitung $\mathrm{K}=\mathrm{TR}-\mathrm{TC}$, dimana $\mathrm{K}=$ Keuntungan, $\mathrm{TR}=$ Total Revenue (total pendapatan), $\mathrm{TC}=$ Total Cost (total biaya). 
B / C Ratio (Benefit cost ratio)

$\mathrm{B} / \mathrm{C}$ Ratio (benefit/cost ratio) diperoleh dengan cara membagikan total hasil produksi

dengan total biaya produksi atau dituliskan dengan rumus :

$\mathrm{B} / \mathrm{C}$ ratio $=$ Total Pendapatan $(\mathrm{Rp}$. Total Biaya Produksi (Rp.)

$\mathrm{B} / \mathrm{C}$ Ratio $>1=$ efesien

$\mathrm{B} / \mathrm{C}$ Ratio $=1=$ impas

$\mathrm{B} / \mathrm{C}$ Ratio $<1=$ tidak efisien

IOFC (Income Over Feed Cost)

Income Over Feed Cost ( IOFC) diperoleh dengan cara menghitung selisih pendapatan usaha peternakan dikurangi dengan biaya pakan. Pendapatan merupakan perkalian antar produksi peternakan atau pertambahan bobot badan akibat perlakuan (dalam Kg hidup) dengan harga jual, sedangkan biaya pakan adalah biaya yang dikeluarkan untuk menghasilkan pertambahan bobot badan ternak.

\section{HASIL DAN PEMBAHASAN}

\section{Analisis Usaha \\ Total Biaya Produksi}

Total biaya produksi atau total pengeluaran yaitu biaya-biaya yang dikeluarkan untuk menghasilkan suatu produk, diperoleh dengan cara menghitung: biaya bibit, biaya kandang dan peralatan, biaya pakan, biaya obat - obatan dan biaya tenaga kerja.

Tabel 1. Rekapitulasi komponen biaya produksi tiap perlakuan selama penelitian (Rp)

\begin{tabular}{llllccc}
\hline \multirow{2}{*}{ Perlakuan } & \multicolumn{5}{c}{ Rataan } \\
\cline { 2 - 7 } & Biaya Bibit & Biaya Pakan & $\begin{array}{l}\text { Biaya } \\
\text { T. Kerja }\end{array}$ & $\begin{array}{c}\text { Biaya } \\
\text { Obat-obatan }\end{array}$ & $\begin{array}{c}\text { Biaya } \\
\text { Kandang }\end{array}$ & $\begin{array}{c}\text { Total Biaya } \\
\text { Produksi }\end{array}$ \\
\hline P0 & 6.103 .575 & 167.005 & 60.000 & 4.500 & 65.000 & 6.400 .080 \\
P1 & 6.014 .550 & 167.746 & 60.000 & 4.500 & 65.000 & 6.311 .796 \\
P2 & 5.960 .850 & 170.481 & 60.000 & 4.500 & 65.000 & 6.260 .831 \\
P3 & 5.973 .825 & 169.398 & 60.000 & 4.500 & 65.000 & 6.272 .723 \\
\hline
\end{tabular}

Berdasarkan Tabel 1 dapat dilihat bahwa total biaya produksi pemeliharaan kerbau Murrah jantan lepas sapih selama penelitian menunjukkan perbedaan diantara perlakuan, dimana rataan total biaya produksi tertinggi terdapat pada P0 sebesar Rp. 6.400.080.- dan 
yang terendah pada perlakuan P2 yaitu sebesar Rp. 6.260.831.-. Hal ini dikarenakan adanya perbedaan jumlah biaya yang harus dikeluarkan untuk pembelian bibit dan pakan. Sementara biaya untuk obat-obatan, upah tenaga kerja, perbaikan kandang dan pengadaan peralatan kandang selama penelitian adalah sama.

Perlakuan P0 (20\% kulit daging buah kopi tanpa fermentasi) memiliki rataan harga bibit yang terbesar diantara keempat perlakuan yaitu sebesar Rp. 6.103.575.-. Sedangkan perlakuan P2 (20\% kulit daging buah kopi fermentasi) memiliki rataan harga bibit terendah dari keempat perlakuan yaitu sebesar Rp. 5.960.850.-. Selain harga bibit, biaya pakan juga mempengaruhi nilai biaya produksi. Dimana biaya pakan pada perlakuan P0 $(20 \%$ kulit daging buah kopi tanpa fermentasi) sebesar Rp. 167.005.- dan pada P2 (20\% kulit daging buah kopi fermentasi) sebesar Rp. 170.481.-. Perbedaan harga bibit dan biaya pakan dalam setiap perlakuan mempengaruhi biaya produksi dalam penelitian ini.

Menurut Siregar (2007) biaya produksi merupakan sejumlah biaya yang dikeluarkan dalam suatu usaha ternak. Biaya ini terdiri dari biaya tetap dan biaya tidak tetap atau biaya variabel. Biaya tetap ini antara lain berupa lahan usaha, kandang, peralatan yang digunakan dan sarana transportasi. Biaya tidak tetap merupakan biaya yang dikeluarkan secara berulang-ulang yang antar lain berupa biaya pakan, upah tenaga kerja, penyusutan kandang, penyusutan peralatan, obat-obatan, vaksinasi dan biaya-biaya lain berupa biaya penerangan atau listrik, sumbangan, pajak usaha dan iuran.

Perbedaan total biaya produksi dari keempat perlakuan dapat dilihat pada Gambar 1 .

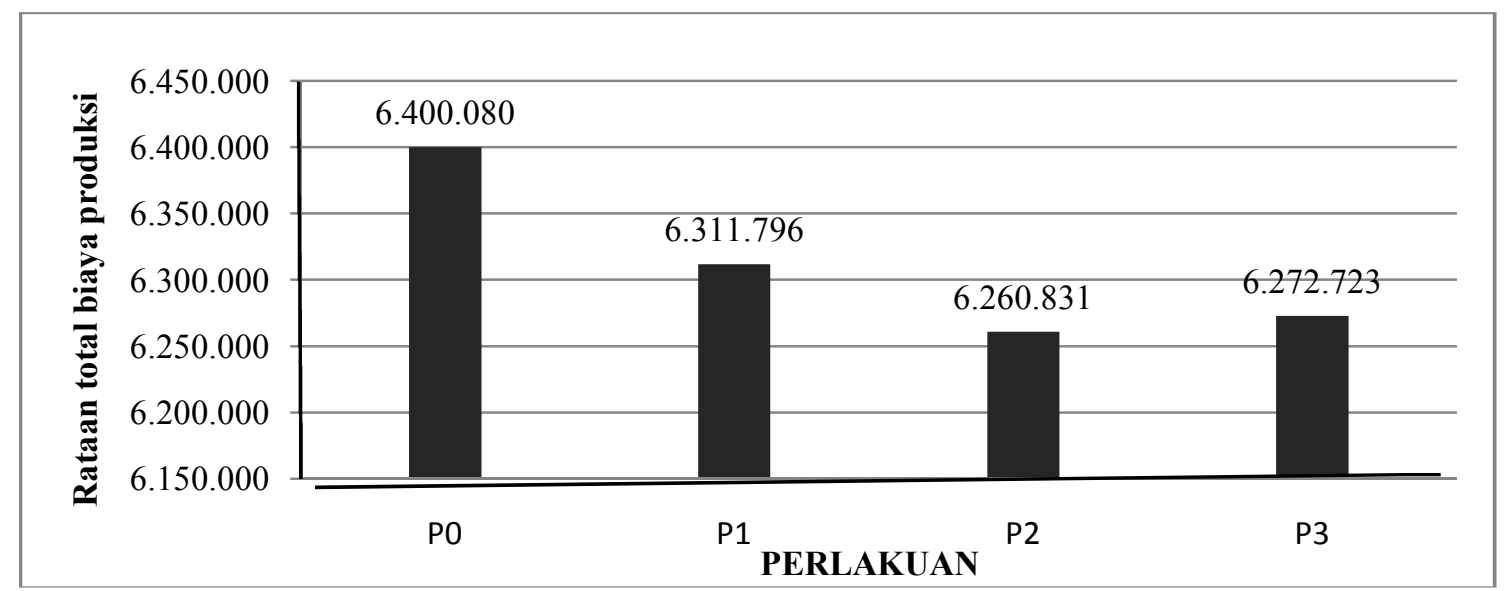

Gambar 1. Grafik Rataan Total Biaya Produksi selama Penelitian. 


\section{Total Hasil Produksi}

Total hasil produksi atau total penerimaan yaitu seluruh produk yang dihasilkan dalam kegiatan pemeliharaan kerbau ini yang diperoleh dengan cara menghitung harga jual kerbau dan feses.

Tabel 2. Rekapitulasi komponen total hasil produksi selama penelitian (Rp)

\begin{tabular}{lccc}
\hline Perlakuan & \multicolumn{3}{c}{ Rataan } \\
\cline { 2 - 4 } & Hasil Penjualan Kerbau Murrah & Feses & Total Hasil Produksi \\
\hline P0 & 6.488 .325 & 50.000 & 6.538 .325 \\
P1 & 6.577 .050 & 50.000 & 6.627 .050 \\
P2 & 6.446 .325 & 50.000 & 6.496 .325 \\
P3 & 6.421 .125 & 50.000 & 6.471 .125 \\
\hline
\end{tabular}

Tabel 2 dapat dilihat bahwa rataan total hasil produksi pemeliharaan kerbau Murrah jantan lepas sapih selama penelitian menunjukkan perbedaan diantara perlakuan, dimana rataan total hasil produksi tertinggi terdapat pada perlakuan P1 sebesar Rp. 6.627.050.- dan yang terendah pada P3 sebesar Rp. 6.471.125.-.

Hal ini terjadi karena adanya perbedaan pertambahan bobot badan kerbau selama penelitian, sehingga nilai pendapatan dari penjualan kerbau berbeda pada setiap perlakuan. Dimana berdasarkan hasil diperoleh perlakuan P1 yang memakai 10\% kulit daging buah kopi yang difermentasi memiliki hasil penjualan kerbau tertinggi yaitu sebesar Rp. 6.577.050.- dan yang terendah pada perlakuan P3 yang memakai 30\% kulit daging buah kopi yang difermentasi yaitu sebesar Rp. 6.421.125.-.

Kondisi ini terjadi karena perlakuan yang mengandung kulit daging buah kopi fermentasi lebih disukai oleh ternak kerbau karena aromanya yang wangi sehingga meningkatkan palatabilitas pada pakan tersebut dan mampu memberikan hasil produk (pertambahan bobot badan) terbaik daripada perlakuan yang mengandung kulit daging buah kopi tanpa fermentasi. Sehingga diperoleh perbedaan pertambahan bobot badan kerbau yang berkorelasi dengan harga penjualan kerbau yang mempengaruhi biaya hasil produksi dalam penelitian.

Tata cara penentuan nilai pendapatan yang dilakukan dalam penelitian ini sesuai dengan pernyataan Budiono (1990) yang menyatakan bahwa penerimaan adalah hasil penjualan output yang diterima produsen. Penerimaan dari suatu proses produksi dapat dihitung dengan mengalikan jumlah produksi yang dihasilkan dengan harga jual produksi tersebut. 
Perbedaan total hasil produksi dari keempat perlakuan dapat dilihat pada Gambar 2.

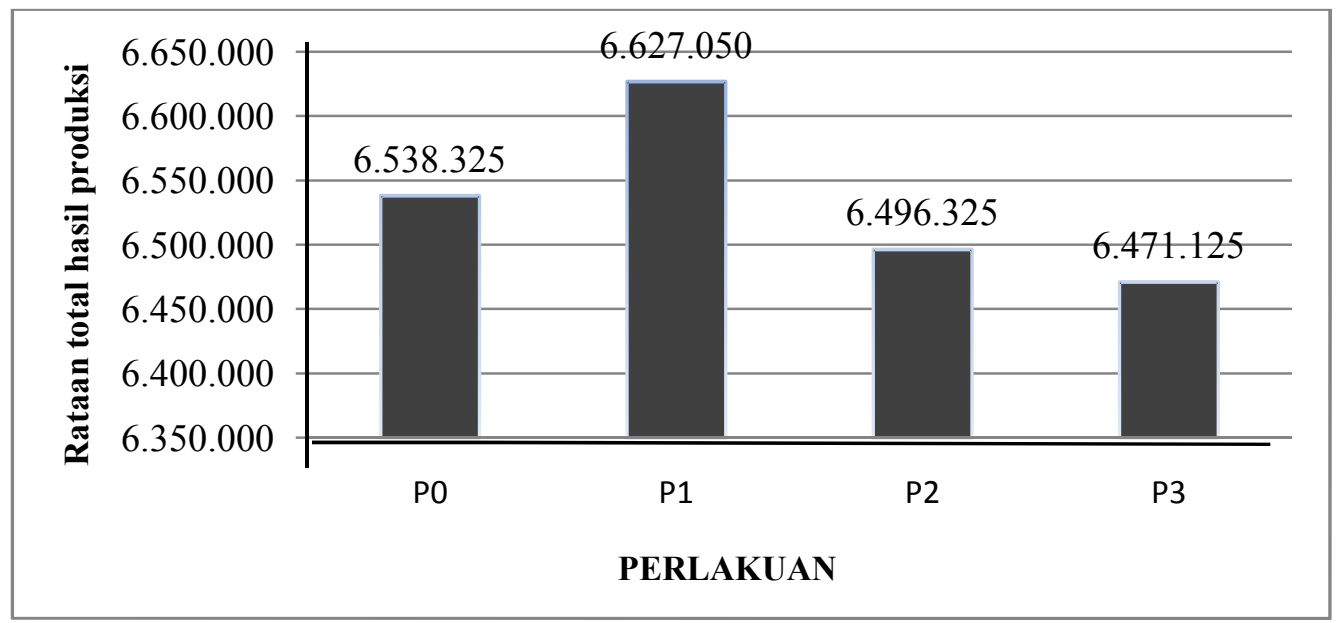

Gambar 2. Grafik Rataan Total Hasil Produksi selama Penelitian.

Tabel 3. Rekapitulasi rataan hasil penelitian

\begin{tabular}{lccl}
\hline & \multicolumn{3}{c}{ Parameter } \\
\cline { 2 - 4 } Perlakuan & Laba/rugi (Rp) & B/C & IOFC (Rp) \\
\hline P0 & 138.245 & 1,02 & 217.745 \\
P1 & 315.254 & 1,05 & 394.754 \\
P2 & 235.495 & 1,04 & 314.995 \\
P3 & 198.402 & 1,03 & 277.902 \\
\hline
\end{tabular}

\section{Analisis Laba/Rugi}

Analisis usaha atau laba-rugi dilakukan untuk mengetahui apakah usaha tersebut untung atau rugi dengan cara menghitung selisih antara total hasil produksi. Berdasarkan Tabel 3 dapat dilihat bahwa rataan laba/rugi menunjukkan perbedaan yang sangat besar, dimana rataan tertinggi terdapat pada perlakuan P1 yang memakai 10\% kulit daging buah kopi fermentasi yaitu sebesar Rp. 315.254.- dan rataan terendah terdapat pada perlakuan P0 yang memakai $20 \%$ kulit daging buah kopi tanpa fermentasi yaitu sebesar Rp. 138.245.-.

Hal ini dikarenakan adanya perbedaan hasil penjualan ternak kerbau yang diterima dengan besarnya biaya yang telah dikeluarkan. Kerbau yang mendapat perlakuan P1 (10\% kulit daging buah kopi fermentasi) mempunyai kenaikan bobot badan tertinggi yang berkorelasi dengan nilai penjualan tertinggi sehingga menghasilkan laba tertinggi juga. Hal ini sesuai dengan pendapat Soekartawi et al. (1986) yang menyatakan bahwa keuntungan (laba) suatu usaha ditentukan oleh selisih antara total penerimaan (total reserve) dan total pengeluaran (total cost) atau secara matematis dapat dituliskan K= TR-TC. Murtidjo (1995) 
berpendapat bahwa bila suatu usaha peternakan dapat mengontrol konsumsi dan harga pakan serendah mungkin tanpa mengabaikan kualitas dari pakan tersebut maka akan diperoleh keuntungan dari usaha peternakan tersebut.

\section{Analisis Benefit/Cost Ratio (B/C Ratio)}

Analisis B/C Ratio digunakan dalam suatu usaha untuk mengetahui layak atau tidak usaha itu untuk dilanjutkan ke periode berikutnya atau sebaliknya usaha tersebut dihentikan karena kurang layak. Tabel 3 menunjukkan bahwa rataan $\mathrm{B} / \mathrm{C}$ ratio yang diperoleh menunjukkan bahwa pemberian kulit daging buah kopi fermentasi dengan mikroorganisme lokal dalam pakan kerbau Murrah jantan lepas sapih dapat dilanjutkan/layak karena rataan dari semua perlakuan memiliki hasil rataan sebesar $1,01(\mathrm{~B} / \mathrm{C}=1)$. Dengan nilai rataan $\mathrm{B} / \mathrm{C}$ ratio tertinggi terdapat pada perlakuan $\mathrm{P} 1$ yaitu sebesar 1,05 dan nilai rataan $\mathrm{B} / \mathrm{C}$ ratio terendah diperoleh pada perlakuan P0 yaitu sebesar 1,02. Hal ini seperti yang dinyatakan Kadariah (1987) menyatakan bahwa untuk mengetahui tingkat efesiensi suatu usaha dapat digunakan parameter yaitu dengan mengukur besarnya pemasukan dibagi besarnya korbanan, dimana bila : B/C Ratio $>1=$ efesien, $\mathrm{B} / \mathrm{C}$ Ratio $=1=$ impas dan $\mathrm{B} / \mathrm{C}$ Ratio $<1=$ tidak efisien.

\section{Income Over Feed Cost (IOFC)}

Income Over Feed Cost (IOFC) adalah selisih dari total pendapatan usaha peternakan dikurangi biaya pakan. Income Over Feed Cost (IOFC) ini merupakan barometer untuk melihat besar biaya pakan yang merupakan biaya terbesar dalam usaha pemeliharaan ternak. Berdasarkan Tabel 3 diperoleh rataan Income Over Feed Cost (IOFC) terbesar terdapat pada perlakuan P1 (10\% kulit daging buah kopi fermentasi) yaitu sebesar Rp. 394.754.- dan rataan Income Over Feed Cost (IOFC) terendah terdapat pada perlakuan P0 (20\% kulit daging buah kopi tanpa fermentasi) yaitu sebesar Rp. 217.745.-.

Kondisi ini terjadi karena biaya pakan yang dikeluarkan untuk perlakuan yang mengandung kulit daging buah kopi fermentasi lebih besar daripada perlakuan yang mengandung kulit daging buah kopi tanpa fermenasi. Perlakuan yang mengandung kulit daging buah kopi fermentasi lebih disukai oleh ternak kerbau Murrah sehingga mempengaruhi jumlah pakan dikonsumsi yang berpengaruh pada harga pakan yang harus dikeluarkan untuk pengadaannya selama penelitian.

Prawirokusumo (1990) menyatakan bahwa IOFC adalah selisih antara pendapatan usaha peternakan terhadap biaya pakan. Pendapatan ini merupakan perkalian antara produksi 
peternakan dengan harga jual, sedangkan biaya pakan adalah jumlah biaya yang dikeluarkan untuk menghasilkan ternak tersebut.

Demikian juga pernyataan Hermanto (1996) yang menyakan bahwa selain pegangan berproduksi secara teknis juga diperlukan pegangan berproduksi dari segi ekonomi, beberapa tolak ukur yang dapat digunakan untuk pegangan berproduksi adalah IOFC (income over feed cost) atau selisih pendapatan usaha peternakan dengan biaya pakan. Pendapatan merupakan perkalian antara hasil produksi peternakan (kilogram hidup) dengan harga jual. Sedangkan biaya pakan adalah jumlah biaya yang dikeluarkan untuk menghasilkan kilogram bobot hidup.

\section{KESIMPULAN}

Berdasarkan hasil penelitian dapat disimpulkan bahwa pemanfaatan kulit daging buah kopi yang difermentasai dengan mikroorganisme lokal dalam pakan kerbau Murrah jantan mampu menambah keuntungan bagi usaha peternakan kerbau Murrah terutama sampai pada tingkat $10 \%$.

\section{DAFTAR PUSTAKA}

Budiono. 1990. Ekonomi Mikro. Seri Sinopsis Pengantar Ilmu Ekonomi No.1. Edisi kedua, Cetakan ke II. BPFE, Yogyakarta.

Hermanto, F. 1996. Ilmu Usaha Tani. Penebar Swadaya, Jakarta.

Kadariah. 1987. Pengantar Evaluasi Proyek. Lembaga Penelitian Fakultas Ekonomi Universitas Indonesia, Jakarta.

Murtidjo.1995. Analisa Usaha Beternak Sapi Potong Intensif. Penebar Swadaya. Jakarta. Nugroho.C.P. 2008. Agribisnis Ternak Ruminansia. Macanan Jaya Cemerlang. Jakarta. Prawirokusumo, S. 1990. Ilmu Gizi Komparatif. BPFE. Yogyakarta.

Sastrosupadi, A. 2000. Rancangan Percobaan Praktis Bidang Pertanian. Edisi Revisi. Kanisius. Yogyakarta.

Siregar. S. B. 2007. Penggemukan Sapi. Penebar Swadaya. Jakarta.

Soekartawi, J., L. Dillon, J. B. Hardaker dan A. Soeharjo. 1986. Ilmu Usaha Tani dan Penelitian Untuk Pengembangan Petani Kecil. Universitas Indonesia- Press. Jakarta.

Tillman, A.D., Hartadi, N., Reksohadiprodjo, S., Prawirokusumo, S., dan Lebdosoekojo S, 1991. Ilmu Makanan Ternak Dasar. Gadjah Mada University Press. Yogyakarta. 